\title{
2 \\ The Release of Cosmic Cows
}

In the Rigveda (Sanskrit: Rgveda), the earliest extant sacred text of India, we find this passage in a celebrated hymn dedicated to the storm-god Indra. The poet tells of Indra's victory over Vritra, a serpent monster, and of the cosmic waters' subsequent release from the serpent's grip. As his victory award, Indra then claims the prized soma drink:

... Like bellowing milk-cows, streaming out, the waters went straight down to the sea. Acting the bull, (Indra) chose for his own the soma. He drank of the pressed soma among the Trikadrukas ...

Later in the same hymn, the poet describes the waters' condition prior to their release by Indra, whom he then addresses:

The waters stood still— their husband was the Dāsa; their herdsman, the serpent [Vrtra] — hemmed in like the cows by the Pani. What was the hidden opening for the water-that Indra uncovered after he smashed Vrtra. You, Indra, then became the tail of a horse when he struck his fangs at you-you, 
the god alone. You conquered the cows, and, o champion, you conquered the soma. You set loose the seven rivers to flow. ${ }^{1}$

Within this short sampling of Rigvedic poetry is a web of names, images, concepts, and narrative that, with all its obscurity for us modern readers, will serve well as a starting point for our journey through literatureancient to modern - to sketch the main contours of a Hindu imaginaire of cows, what we might venture to call bovinity. What we want to note initially from this hymn is simply how it is an indicator that cows are very much a presence in Hindu literature, beginning already from this early text. $^{2}$ Over at least three millennia, people of South Asia have engaged with domesticated bovines as integral to their economic livelihood and their cultural and spiritual well-being, and this is richly reflected in their literature. In our survey of this corpus, we will focus mainly on the texts most prominent and revered in the tradition, especially of the brahmanical, or priestly, classes who have produced and preserved them. For the most part we are concerned with texts composed in Sanskrit, though we will also look briefly at later works in modern Hindi.

What the Rigveda and the post-Vedic corpus (including the Sanskrit epics and Puranas ${ }^{3}$ ) as a whole shows is a constellation of associations in which cow — whether referred to literally or figuratively-holds an important, often key, place in articulating notions of cosmic order and regularity, fecundity and abundance, auspiciousness of circumstances, human possession of wealth, general well-being, life as it is meant to be lived, and related notions of desirability. When bulls are mentioned in distinction

\footnotetext{
${ }^{1}$ Rigveda translation-Jamison and Brereton (2014, p. 135; vv. i.32.2, 11-12). All subsequent Rigveda quotations translated by Jamison and Brereton.

${ }^{2}$ As I have noted in the Introduction, the term "Hindu" can be problematic. I use it largely as an inclusive term of convenience, recognizing that, while historically it is an anachronism to refer to early texts such as Rigveda as Hindu, the much later and present-day identification of a broad corpus of literature as Hindu by persons regarding themselves as Hindus justifies this usage. Srinivasan (1979, p. 1) notes that collectively, among the Rigveda's more than one thousand hymns, the seven or eight terms for "cow" appear almost 700 times, more than any other animal. Of these terms, gó is the most inclusive.

3"Epics" refers to the two classical Sanskrit epic poems, the Valmiki Ramayana and the Mahabharata, both of which are generally given several centuries of developmental time, typically from the 5th c. BCE to the 4th c. CE (Brockington 2003, p. 116). "Puranas" ("ancient lore") are several texts of varying length and focus, with the earliest extant Puranas usually dated to the 4 th to 5 th c. CE, and later Puranas dating up to the 16th c. or even later.
} 
from cows, further notions of righteous virility and power are added to this constellation of meaning. But as we might expect, over such a vast time period there are shifts and reshapings of this semantic field. From one perspective-typically that of Hindus - these are not so much changes in understanding as they are reiterations and amplifications of persistent concerns, attitudes, and truths in relation to cows. In any case, what we find in later literature is elaboration, especially through narratives, of what may be in only germinal form in the earliest literature.

Of particular interest to us will be narratives in the Bhagavata Purana (usually dated 4th-9th c. CE), a text of enduring pan-Indian popularity due especially to its detailed account of the irresistably charming cowherd divinity Krishna in the ideal and idyllic land of cows, Vraja. What will be important to consider here will be how the notion of cow care is interwoven with the major current of Indic religiosity known as bhakti-devotion to a particular divinity, especially to Krishna or Shiva, or possibly to the divine feminine in a form such as Parvati. Also, because it is Krishna in particular who is associated with cows, we find a wealth of post-Bhagavata literature focused on Krishna-bhakti that will concern us with its portrayals of a pastoral world that enhances and sustains divine play (Sanskrit: $l \bar{l} \bar{l} \bar{a}$ ). Looking back in time from the later to the earliest literature, what we will find as a consistent thread, I will argue, is a notion of divine-humananimal cooperation that is sustained in a matrix of ritual and bhakti. Yet this interconnected triangle is at times threatened by adverse forces such that the very possibility of stable worldly well-being is perpetually questioned. This questioning, in turn, brings forth and nurtures renunciant ideologies, which will be crucial for development of the Indic concept and practices of ahimsa-nonviolence. The development of ahimsa ideology will be treated in the next chapter.

\section{The Rigveda-Cows Ranging in Meaning}

The Rigveda, generally considered the earliest of four collections of sacred utterances, assembled probably well before $1000 \mathrm{BCE}$, enjoys a position of 
highest regard and authority by most, if not all, persons who would identify themselves as Hindu (Smith 1998, pp. 13-14). ${ }^{4}$ By modern scholarly estimation, it is "the oldest literary monument of the Indo-European languages" and, indeed, "one of the oldest and most precious documents of man" (Myers 1995, p. 25, quoting Macdonell 1917, p. xi; Maurer 1986, p. 1). And although but a tiny number of Hindus have any idea of its specific content; their reverence for the work is evident in its continued application in ritual practices to the present day. Pundits (scholars or priests learned in Hindu sacred texts) are similarly revered as custodians of Vedic writ, and it is likely they who will be most ready to affirm with Rigveda excerpts the sanctity of cows. Thus, we do well to examine Rigvedic bovine references to gain a sense of the value system in which cows are so important and within which the term "cow" plays a significant role in a dynamic web of meanings.

In the Rigveda hymn quoted above, the poet employs cows and a bull figuratively in connection with water and Indra, respectively; also, the poet alludes, within the main narrative of Indra's victory, to another Rigvedic narrative about cow confinement that we will discuss later. The motif of confined cows released, often identified with their milk-giving capacity, points to a broad Vedic symbol for flourishing life: freely roaming and grazing milk-producing cows seek and find their watering place (Myers 1995, p. 40). In direct opposition to flourishing life is constriction or obstruction (vritra, Sanskrit vrtra, means "obstacle") which is, or brings about, decay, destruction, chaos, and death. Here, the waters' freedom is constrained by their "husband," identified as the Dasa (Sanskrit: Dāsa) people—essentially "outsiders" to the Rigvedic community, which designated itself as Aryan peoples, roughly "the civilized ones" (Jamison and Brereton 2014, p. 54).

Indra, the hero in this narrative, is the powerful storm-god, often regarded as the king of the heavenly realm. He is repeatedly praised in the Rigveda for his indomitable bull-like valor, often in the context of

\footnotetext{
${ }^{4}$ Smith writes, "Hinduism is the religion of those humans who create, perpetuate, and transform traditions with legitimizing reference to the authority of the Veda." This definition that looks back in time may be augmented by Frazier (2017, p. 21), who notes, "The Vedic tradition ... is a bricolage that developed over two millennia into a complex culture that turned again and again to its source in order to renew its identity."
} 
recalling his having slain the serpent monster Vritra. In this and numerous other Rigveda hymns, the implication is that as he prevailed in the past he shall prevail again, this time on behalf of the petitioner(s). And it is Indra, in particular, who is regarded as the rightful claimant of the prized juice of the soma plant, an invigorating, apparently intoxicating, probably psychotropic drink that was ritually prepared and offered in major sacrificial rites. Significantly, the ritual preparation of the soma drink involved mixing it with water and milk prior to offering it. ${ }^{5}$ As an essential ingredient of this crucial offering, milk is frequently identified metonymically with cows, or simply referred to as cows. Finally, in reference to the passage quoted above, Indra's valor is underlined in the affirmation that he "conquered the cows" at the same time that he "conquered the soma." Indra is an aggressive and confrontational divinity (Glucklich 2008, p. 96), but he thereby accomplishes the needful: "You set loose the seven rivers to flow."

As a predominantly pastoral people, the Vedic Aryans were naturally concerned to acquire, retain, and protect their cattle from predators and rustlers. To do so successfully was largely a function of generously sponsored, well-executed ritual performance, broadly referred to as yajna, roughly translated as "sacrifice" but also meaning "act of worship or devotion, offering, oblation." Efficacious ritual required, in turn, the engagement of expert priests, brahmins who, like their sponsors, would likely be keepers of cattle. Many of the Rigvedic hymns reflect these considerations, such that much poetic attention is given to inspiring a ritual's divine dedicand to be generous in his (or in some cases her) rewards to the sponsors and priests. One example showing this concern is Rigveda 2.11. Again, the dedication is to Indra:

Drink and drink the soma, o Indra, our champion! Let the exhilarating soma-pressings exhilarate you. As they fill your cheeks, let them strengthen you. When properly pressed among the Paura, (the soma) has helped Indra.

We inspired poets have abided by you, Indra. Serving according to the truth, we would gain insight. Seeking your help, we would create for ourselves a proclamation of your praise. On this very day, we would be those to be given wealth by you.

\footnotetext{
${ }^{5}$ For a detailed description of a contemporary agni-shtoma sacrifice including the preparation and offering of soma, see Knipe (2015, pp. 212-214).
} 
Then, in the same hymn, Indra is again urged to drink the soma "among the Trikadrukas" (possibly referring to the Maruts, a group of divinities associated with the wind). Again, Indra is reminded that he has slain Vritra, by which, this time, he "uncovered the light for the Arya"; and there is again allusion to the second cow-confinement narrative involving Indra, whereby cows had been hidden in "the Vala cave." The hymn concludes:

Now should the generous priestly gift yield your boon for the singer as its milk, Indra. Exert yourself for the praise singers. Let fortune not pass us by. May we speak loftily at the ritual distribution, in possession of good heroes. ${ }^{6}$

Here "milk" is the reward rendered presumably to the poet who has composed the hymn, through the (obligatory) "gift" (dakshina) given to the priests who have performed the rite in which this hymn would have been recited.

We begin to see the contours of a Vedic cosmic economy, in which three interrelated spheres of life_-natural, human, and divine-interact for mutual benefit. ${ }^{7}$ In this economy, cows and their products-especially milk - are indispensable. While providing milk and its derivatives that give nourishment for the cows' young and for humans, they also contribute, by their milk, in the preparation of the crucial ritual offering, soma.

We also see contours of Vedic Aryan self-perception as a people threatened by outsiders. Thus, at times Aryans are engaged in battles with their enemies - various sorts of beings (human or nonhuman) associated with darkness. Between the darkness and the light, serving to end darkness and bring on the light, is the dawn. Connecting the cosmic light versus darkness opposition with the Aryans' experience of themselves versus their enemies, some Rigvedic hymns celebrate the dawn as the great Distinguisher which, as an essential, life-giving and sustaining aspect of nature

\footnotetext{
${ }^{6}$ Rigveda 2.11.11-12, 17a, 18, 21 and Jamison and Brereton (2014, pp. 414-415).

${ }^{7}$ Having registered such conceptualization, we do well to also heed A. T. de Nicolás' caution in reading the Rigveda (1976, p. 11): "It is ... essential ... that we get ourselves ready to move, in one swift jump, from the prosaic, discursive, lengthy and conceptual ground on which we are accustomed to stand, into the moving, shifting, resounding, evanescent, vibrating and always sounding silence of the musical world on which the Rg Veda stands" (emphasis in original). See de Nicolás, pp. 13-15, for a succinct overview of Eastern and Western Rigveda exegetical approaches.
} 
like water, is also identified as "cows." ${ }^{8}$ In turn, the cows = dawns signification serves also the linkage between cows and the soma yajna, for it is at the time of the morning pressing of the soma juice (which, we recall, is mixed with cows' milk) that priestly gifts are distributed, among which may be cows.

In such a culture wherein ritual plays such a major role, it may be no surprise that the gifting of cows to priests at the conclusion of their ritual services in the yajna has itself ritual aspects. And so, there is a charming Rigvedic hymn (6.28) dedicated to cows which, it is surmised, may have originally been sung "to bless the cows given as a dakshina (priestly gift) as they enter the home of their new owner" (Jamison and Brereton 2014, p. 812). We may note the sorts of dangers to cows that are being warded off by the blessing:

These [cows] will not be lost, and no thief will take them by deception. No enemy will venture against their meandering course. Those (cows) with which he [the cow owner] sacrifices and gives to the gods, he keeps company with them as their cowherd for a very long time.

No dusty-necked steed gets to them (in a cattle raid), nor do they go to the place for dressing [=slaughterhouse]. The cows of the mortal who sacrifices wander far across wide-ranging (space) free of fear.

Continuing in the same hymn, the receiver of the gift of cows rejoices, counting the several benefits bestowed by them while identifying them with soma and Indra:

Fortune has appeared to me as cows; Indra as cows. The draught of the first soma is cows. These cows here-they, o peoples, are Indra. I am just searching, with my heart and mind, for Indra.

You fatten even the thin man, o cows. You make even one without beauty to have a lovely face. You make the house blessed, o you of blessed speech. Your vigor is declared loftily in the assemblies.

\footnotetext{
${ }^{8}$ For example, see RV 3.31.4: “The victorious (clans [=Angirases?]) escorted the contender [=Indra?]. They distinguished the great light from the darkness. Recognizing him, the dawns rose up in response. He became the lone lord [/husband] of the cows-Indra" (Jamison and Brereton 2014, p. 509; bracketed terms in original).

${ }^{9}$ Rgveda 6.28.3-6; Jamison and Brereton (2014, pp. 812-813).
} 
There is assuredness of well-being in this hymn, based on the presence of cows which-it is hoped and expected by the owner-themselves will experience well-being and indeed "enjoyment" (Rigveda 6.28.1). ${ }^{10}$ Cows are regarded as ever givers, and as such they are identified with creation and sustenance, motherhood, fertility, and liberality. They are therefore associated or identified with cosmic waters, which are like the lowing cows that flow with milk. Further, "rain is shed as milk from cows; poetic vision is like a cow flowing with a thousand streams of milk; the breasts of a goddess are like the cow's udder" (Srinivasan 1979, p. 4).

Especially from the last two verses quoted, we get a deeper sense of how cows were highly valued by Rigvedic Aryans. Now we are in a position to appreciate the significance of the story of cows' confinement in the second narrative alluded to in our initial Rigveda excerpt (in 1.32), where it was mentioned that the waters were "hemmed in like the cows by the Pani." In the story of the Panis, cows, horses, and other treasures are stolen by a group of opposers to the Vedic sacrifice - the demonic Paniswho keep the booty hidden in a cave, or within a great rock. To recover these valuables, Indra dispatches his messenger Sarama (in the form of a female dog); the latter, confronting the Panis with threats, tries but fails to persuade the Panis to relinquish the goods. Finally, by force of sacred utterances (mantra) Brihaspati, the chief divine priestly assistant to Indra, smashes asunder the enclosure and reclaims the treasures, including, of course, the cows. ${ }^{11}$

This story is important for its celebration of the Vedic sacrificial way of life, whereby cosmic order, rooted in the mysterious ordering principle rita (Sanskrit: $r t a$ ), positions human beings as intermediaries between the tangible world of nature and the invisible world of the gods - the divine. Vedic yajna is an act of generosity, a display of largess. The Panis (pani

\footnotetext{
${ }^{10}$ One Atharvaveda hymn addresses a cow, in the context of donating a bull to a brahmin (priest): "This young male we set toward you here; with him go you (fem.) playing according to your wills..." (Whitney, 2009, p. 240). Playing (krīdantī) according to their wills (vaśam anu) indicates a sense of bovine's subjectivity.

${ }^{11}$ Tales involving bovines are present in several mythological traditions of the world, some of which show interesting parallels with Vedic or post-Vedic accounts of bovines. For example, in south and southeast Asia, several versions of the epic Ramayana tell of a buffalo demon who is encountered and killed by the monkey king Vali in a cave-in some versions enabling Vali to get free from the cave. See Kam (2000, pp. 85-89).
} 
elsewhere in the Rigveda means "miserly") are the opposite of the Aryan sacrificers, and their formidable effort to prevent the sacrifice must be overcome. But this is possible only with the same technology as constitutes the sacrifice, namely well-composed and properly uttered hymns and mantras.

The web of bovine signification in the Rigveda (and in related ritual texts) expands considerably, as cows become associated with speech itself, especially the poetic speech of Vedic hymns, also referred to as mantras. As cows are embodiments of wealth and well-being, rightly pronounced speech facilitates successful sacrificial rites by which, in turn, cattle may be awarded. ${ }^{12}$ Indeed, the most basic component of speech, the syllable (akshara, meaning unbreakable, irreducible, inexhaustible) is identified with "cow" (Jamison and Brereton 2014, p. 882; Rigveda 7.1.14). ${ }^{13}$

We can make a few generalizations about cows in the Rigveda before moving on to the Upanishads. First, we can see the text as a whole as modeling the proper (right) way of living for human beings. As a means of sensitizing humans to cosmic order, cows are living signs of such order with all their characteristics of giving and nurturing. Second, in the sphere of material well-being, possession and care of cows is integral to right living, and such well-being is embodied and sustained in ritual acts of

${ }^{12}$ Indeed, in a later reflection on Vedic ritual, in the Brihadaranyaka Upanishad (5.5.8; Olivelle 1998 , p. 135), the equivalence of speech and the cow extends to an equation of her four teats with four important syllable pairs pronounced in fire rites: "One should venerate speech as a cow. It has four teats-Svāhā, Vasaț, Hanta, and Svadhā. The gods live on two of those teats—Svāhā and Vaṣaṭ. Humans live on Hantā, and the ancestors on Svadhā. The bull of this cow is the breath, and her calf is the mind." Beyond the award of cattle for correctly performed ritual and correctly pronounced speech in the ritual was the award of freedom from death. This will be elaborated in later texts, especially the Brihadaranyaka Upanishad and the Shatapatha Brahmana (Calasso 2015, p. 34). This is also alluded to within the Rigveda, for example I.154.6: "We wish to go to the dwelling places belonging to you two [=Viṣnu and Indra], where there are ample-horned, unbridled cows" (Jamison and Brereton 2014, p. 331).

${ }^{13}$ We have barely scratched the surface of cow associations in the Rigveda and other Vedic texts, especially the Atharvaveda. For a quite thorough referencing and analysis of these associations, see Gonda (1985, pp. 39-53). The web of bovine signification extends yet further when words indicating parts of a cow's body are included. So, for example, the word padá means "cow's hoofprint"; and it also means track, sojourn, region, (metrical) foot, radius, (single) word, and speech. Calasso (2015, p. 19) notes, "If we are talking about the 'hidden padá, [Louis] Renou says it is 'the mystery par excellence, which the poet tries to reveal'. Already we are a long way from the cow's hoof print, which itself is mysterious and venerable, since a special 'libation on the hoof print,' padähuti, is dedicated to it." 
sacrifice. As a consequence, third, literal, actual cows are sought after, as wealth and - of equal or greater importance-prestige, which is regarded as a requirement for achieving human dignity. Fourth, metaphorical cows expand meaning by linking natural phenomena and elements to human existence, especially embodied in the feminine maternal principle. Again, related to the fourth point, value in the paradigmatic human activity of yajna is underscored with the correct recitation of appropriate hymns. In their expansion of meaning, cows tend to wander, and in their wandering, they embody the human pursuit of the unknown (Srinivasan 1979, p. 7), which is a central theme in the next important genre of early Sanskrit texts associated with Hindu traditions, the Upanishads.

\section{The Upanishads-Cows and the Acquisition of Higher Knowledge}

We step forward in time from the Rigveda to the early formation of a new genre of texts, appearing by the sixth century BCE, a genre that comes to be known as Upanishad (Sanskrit: upanisad), "to sit down near" (the spiritual teacher earnestly) (Grimes 1996, p. 330). The Upanishads are known for their philosophically reflective character, with discussions conducted mainly in the form of dialogues between teacher and student. In their general pursuit of higher knowledge prompted by fundamental, existential questions (especially, What is the nature of the self? What is the basis of all existence?), they offer engaging interlocutions in which occur occasional, tangential yet telling references to cows. As noted with regard to Rigvedic bovinity, where emerges a sense of association between cows and pursuit of the unknown, cows and concerns about cows in the Upanishads hint strongly of this connection. Also related to our theme of Hindu animal ethics as a whole, the Upanishads are important as a record of a developing renunciant ideology, for which the concept and practice of nonviolence-ahimsa-becomes important, to be discussed in Chapter 3.

Here we look briefly at two cow-related Upanishadic narratives. The first, found in the early Chandogya Upanishad, concerns a certain young boy, Satyakama Jabala, whose strong urge to receive higher knowledge from sage Haridrumata Gautama is eventually rewarded. First, however, 
the lad must prove his resolve and sincerity by service. The service task assigned is to tend (anusamvraja) four hundred of the sage's leanest and feeblest (nirakritya) cows. Satyakama promises that he will not only do this, but that he "will not return without a thousand" (cows). Some years later, this number of cattle is reached, at which time "the bull" (rishabha) speaks to the lad, informing him that this number has been reached and requesting him to bring them all back to the master. "Take us back to the teacher's house, and I will tell you one quarter of brahman."

Brahman, the mysteriously ineffable ultimate reality that is such a major subject of the Upanishads, will now be revealed to Satyakama in four phases, first by the bull, then by fire, third by a gander, and finally by a water bird. When, after four days of travel herding the cattle, Satyakama arrives before Gautama, the latter calls out, "Son, you have the glow of a man who knows brahman! Tell me-who taught you?" Satyakama (satya means "truth": he who desires truth) tells all of what has happened and then requests the teacher to give him the same teaching "for I have heard from people of your eminence that knowledge leads one most securely to the goal only when it is learnt from a teacher." Gautama is apparently pleased, such that he gives Satyakama the teaching "without leaving anything out" (Chandogya Upanishad 4.4-9; Olivelle 1998, pp. 219-223). ${ }^{14}$

Here the connection between service to a teacher and knowledge received from the teacher is clearly underlined; yet we may note that the service rendered is caring for cows. ${ }^{15}$ Moreover, that the first teaching (in this account) about brahman comes from the mouth of a bull is worth noting. Here we find a direct connection made between cows (here used

\footnotetext{
${ }^{14}$ The satisfaction of the teacher by tending his cows finds expression in a somewhat similar story of Upamanyu in the Mahabharata. Feller notes that it may be significant that in both these accounts, the students' tending cows may be signaling the boys' isolation in the forest, as a preliminary preparation for initiation. That they are also tending cows during this time suggests additional auspiciousness and purity accruing to the candidates for higher knowledge. Incidentally, the Upamanyu story also finds resonances in the Rigveda (Mahabharata 1.3.19-31; see Feller 2004, pp. 208-211, 216, 227; also see 242-245, on a different, significant account of Upamanyu, later in the Mahabharata).

${ }^{15}$ In a contemporary popular book of stories about cow protection (go-raksa), the author urges his readers to understand that Satyakama's service is for the cows, and that it is because he serves the cows that he is rewarded with knowledge of brahman (Das 2013, pp. 35-37).
} 
as a gender-inclusive term) and higher knowledge that would seem to be only obliquely pursued in Rigvedic hymns. ${ }^{16}$

The other cow-related passage from the Upanishads to concern us is in the Katha Upanishad, a somewhat later work than the Chandogya. The Upanishad opens with this curious scene: A certain young man, Nachiketas, watches while his father, Ushan, gives away all his possessions in charity, or as sacrificial gifts. Among his possessions were old, barren cows. As the cows are being led away, the boy thinks,

They've drunk all their water, eaten all their fodder, they have been milked dry, they are totally barren-'Joyless' are those worlds called, to which a man goes who gives them as gifts.

Testily Nachiketas asks his father, "Father, to whom will you give me?" Annoyed and impatient with his son (who repeats the same question thrice), Ushan blurts out "I'll give you to Death!"- -so that Nachiketas proceeds immediately to the abode of Yama, the lord of death. As it happens, Yama is absent from home for three days while Nachiketas waits for him. Upon his return, Yama anxiously offers to fulfill three wishes, in recompense for the three nights that the young man, a brahmin (who should by no means be neglected), had been kept waiting. Nachiketas obliges, first with two simple wishes that Yama happily and immediately grants; but at his third wish-to receive instruction from Yama on whether or not a person who dies continues to exist or not-Yama balks, unwilling to reveal this great secret.

Initially Yama tries to offer substitutions for Nachiketas' wish, in the form of long life, beautiful women, a vast kingdom, and "much livestock." The point for us to note here is that what was so much sought after in the Rigveda, including wealth in the form of cattle (which Nachiketas

\footnotetext{
${ }^{16}$ An intriguing connection between the bull-like god of fire, Agni, the hidden track of the cow, and poetic speech can be found in RV 4.5.3: "A great melody (he [the fire god Agni] gave)—-the doubly lofty, sharp-pointed, thousand-spurting, powerful bull--/having found the word hidden like the track of the cow. Agni has proclaimed the inspired thought to me" (Jamison and Brereton 2014, p. 566). The ways in which higher knowledge is expressed in the Upanishads — especially through homologies — can be traced through the language of the post-Vedic Brahmana texts back to Rigvedic poetic expressions (see Witzel 2003, p. 83).
} 
perceives his father as giving begrudgingly), is of no interest to this Upanishadic seeker of enduring truth beyond the apparent truths of temporal life. ${ }^{17}$ Times have changed. The Vedic pastoral way of life fades as towns have grown and sociopolitical order has become more complex. And with these new circumstances comes, for many, a resolve to head for the forest to embrace austerities and aloofness from worldly cares, taking the way of disengagement (nivritti) and spurning the way of engagement in the world (pravritti). With this opposition in mind, we can proceed to bovine representations in the great Sanskrit epic of India, the Mahabharata, wherein the relative value of worldly engagement and disengagement is extensively debated, and cows can prove to have important roles in a human being's destiny. ${ }^{18}$

\section{The Mahabharata-Pursuing Dharma with Cows}

As with the Upanishads, the vast-ranging story of fratricidal war that is the Mahabharata can be seen as a work propelled by fundamental questioning. But whereas the Upanishads are more concerned with knowledge of ultimate being, brahman, in the Mahabharata the central concern is to know what is right behavior-dharma. ${ }^{19}$ The desire to comprehend this elusive term, dharma, is not new with the Mahabharata; the Rigveda also refers to dharma in enigmatic ways - but with the Mahabharata there is a sense of increasingly pressing need to establish unequivocally the principles and practices for human well-being, due to a felt acceleration of time's degrading influence. The vortex of such degradation is seen in the massively destructive war between the five Pandava brothers and their

\footnotetext{
${ }^{17}$ Katha Upanishad 1.1-29 (Olivelle 1998, pp. 375-381).

${ }^{18}$ Discussion of the Bhagavad-gita in relation to cows, and in relation to the issue of violence versus nonviolence toward animals, is relevant in the Mahabharata context, and we take up this subject in Chapter 3.

${ }^{19}$ The word dharma is hugely important in Indic texts (including Jain, Buddhist, and Sikh traditions). With both prescriptive and descriptive uses, in its broadest sense it may simply be rendered as "ethics." It can also carry the sense of "justice," as suggested in some texts that refer to the "dharma bull" (Hiltebeitel 2011, p. 213). More on this subject in later chapters. For an extensive analysis of the development of the notion and use of the term dharma in Indic literature, see Hiltebeital (2011).
} 
cousins, the Kauravas, over the rule of their contested kingdom. In two didactic interludes to the epic's main story-one in the account of preliminary events leading to this war, and another in the account of the war's aftermath-the subject of cows becomes the focus. It is these moments that will occupy us, as indicators of further development of the bovine imaginaire in the early Hindu literary corpus. This development is such as will develop into an explicit link between cows, the care of cows, and human right action, dharma.

The first passage has the prima facie purpose of teaching that the power of brahmins - priests, teachers, or sages - is superior to that of kshatriyas (Sanskrit: ksatriyas) — members of the martial order. ${ }^{20}$ Vasishtha, a brahmin ascetic forest resident, is approached by Vishvamitra, the king of Kushika, while the latter has been hunting deer and boar with his large retinue. The sage warmly welcomes the king to his hermitage, hosting him and his entourage generously with refreshments. The refreshments are of such a fine quality and quantity that the king's curiosity is piqued. How is it possible for Vasishtha, living in such simplicity, without any previous warning, to suddenly supply such goods - not only fruits of the forest, but also grains, milk, clarified butter, and plentiful other comforts, and in such quantities? The explanation is forthcoming: Vasishtha has a special cow named Nandini that — or who-when requested, instantly yields whatever the sage desires.

Seeing the handsome cow, Vishvamitra resolves that he must possess her. But Vasishtha declines the king's offer of ten thousand cows and his entire kingdom in exchange. A battle ensues when Vishvamitra fails to drag Nandini away and Vasishtha calls her to remain with him. The sage's call

\footnotetext{
${ }^{20}$ Although this distinction of brahmins and kshatriyas in terms of a power differential is important in the Mahabharata, also emphasized is the interdependence of the two positions. Biardeau (1997, p. 78 and n. 8) notes that brahmins are generally dependent on the gifts of kshatriyas, typically in the form of gold, cows, and (later) land. They are also (generally) dependent on kshatriyas for protection. Their interdependence is highlighted in the Vedic sacrificial rite, a continuing practice in the Mahabharata (Biardeau 1989, p. 36), at which such gifts will be given by the kshatriya sponsor of the rite as reward to the brahmin for executing the rites. Biardeau also notes, incidentally, that "[Hindu] [m]yths always symbolize the Brahman's [brahmin's] sacerdotal function by means of a cow, and the latter eventually symbolizes the Brahman himself, since a Brahman without a cow is less than a complete Brahman." Because of the brahmin/cow identification, "To kill a cow is almost as abominable as to kill a Brahman, although the revealed texts are categorical: certain rites included a cow as sacrificial victim. But 'to sacrifice is not to kill'” (Biardeau 1989, p. 36).
} 
(following a verbal exchange with the cow) prompts her to manifest from her body hordes of soldiers - tribal peoples who quickly rout, unharmed, Vishvamitra's soldiers. Vishvamitra now understands: kshatriya power is insignificant; brahmin power (tejas) is true power. Resolving to become a brahmin, he abandons his kingdom, takes up extreme ascetic practices, and after years of determined ordeal, is granted recognition as a brahmin. ${ }^{21}$

One implication from this story is that cows show their largesse when cared for by brahmins, and they provide all necessities for them. Brahmins, in turn, possessing the superior power of austerity, are the guardians of a society's higher values. Their strength is in their self-restraint, the basic principle of disengagement from the world (nivritti), a principle that complements and supports the sheltering of bovine animals, which in turn come to embody the observance of dharma-ethical rightness and realization of individual and collective good (Ranganathan 2017, pp. 5-6). ${ }^{22}$

Unlike the Rigveda, which extols the gifting of cows to priests (brahmins) specifically in sacrificial rituals, the Mahabharata emphasizes a more general principle of cow-gifting as charity, especially to brahmins but not necessarily in relation to their ritual acts. Following the Pandava-Kaurava war (a Pyrrhic victory for the dharmic Pandavas), the dying warriorgrandsire Bhishma prepares the chief Pandava, Yudhishthira, for ruling his kingdom by instructing him in all aspects of dharma. Set in this context are several chapters extolling the virtues and benefits of gifting cows, along with explanations about cows' particular virtues.

In one such passage (13.69), Bhishma speaks with unrestrained enthusiasm on this subject. First, he notes that (because the word go can mean "cow," "earth," or "speech") to give cows, earth, or knowledge are of "equal

\footnotetext{
${ }^{21} \mathrm{MBh}$ 1.164-165. A fuller account of this episode is to be found in the Valmiki Ramayana (1.50.20-1.64), the other of the two great Sanskrit epics (Sathaye 2011). For brevity, I have discussed the shorter version in the MBh. However, one point to note from the Ramayana version is that Vishvamitra's initial offer in trade for the cow (in that text referred to as Shabala) is one hundred thousand of his own cows. He then asserts, "[Shabala] is truly a gem, and all gems belong to the king. Therefore, brahman, you must give me Śabala. By rights she is mine” (Goldman 2005, p. 279). ${ }^{22}$ Here I draw on Shyam Ranganathan's general consideration of both ethics and dharma being about the same concerns, namely the right or the good. More on this in Chapter 5.
} 
merit." 23 Further, the merit received by one who gifts cows accrues immediately. Indeed, cows are "the mothers of all creatures," able to "bestow every kind of happiness," for they are "goddesses and homes of auspiciousness" which therefore "always deserve worship." ${ }^{24}$ And yet, although giving cows in charity is strongly encouraged, Bhishma also warns that they should be given only to "deserving" persons. Who are deserving? Bhishma's standard is high: "A cow should never be given unto one that is not righteous in behaviour, or one that is sinful, or one that is covetous or one that is untruthful in speech, or one that does not make offerings unto the Pitris [ancestors] and deities." Bhishma later quotes the lord of death and justice, Yama, speaking to Nachiketas, on positive qualifications for a recipient of $\operatorname{cows}^{25}$ :

He is regarded as a proper person for receiving a cow in gift who is known to be mild towards kine [cows], who takes kine for his refuge, who is grateful, and who has no means of subsistence assigned unto him. (Ganguli 1991, vol. 11, p. 94; Mahabharata 13.71)

Simply by giving cows in charity to a proper recipient and in the proper way one can anticipate the full rewards of eternal transcendence following one's present life. As Yama informs Nachiketas (as told by Bhishma), beyond the heavenly realm, which itself is a place of stunning beauty and exalted pleasure, there are "other eternal worlds" that are "reserved for those persons that are engaged in making gifts of kine" (Ganguli 1991, vol. 11, p. 93; Mahabharata 13.71).

\footnotetext{
23The passage is 13.69 in Mohan Ganguli's English translation (Ganguli 1991 [1970], vol. 11, pp. 88-89), 13.68 in the Mahabharata Critical Edition (Dandekar 1966, vol. 17, pp. 380-382). Here and elsewhere I reference Ganguli's edition, as the "vulgate" version that would be known to many Hindus.

${ }^{24}$ We will consider details of current cow care and veneration practices in Chapter 4. Here we may note three examples of careful treatment of cows (including bulls) mentioned by Bhishma, namely (1) at no time, except when tilling the ground in preparation for a sacrificial rite, may bullocks be struck with a goad or whip; (2) when cows are grazing or lying down, no one should disturb them in any way; and (3) no one should ever deny cows access to any source of water, for them to drink. ${ }^{25}$ Here the MBh gives its own version of the Nachiketas-Yama story from that of the Katha Upanishad. In the Mahabharata version, Yama allows Nachiketas to visit the heavenly realm where, stunned by its beauty, he hears from Yama of the exalted destiny for givers of cows. Yama also prescribes the procedure for donating cows, including consideration of the proper time, the condition of the cows to be donated, and whether the recipient will properly care for them.
} 
Such are the rewards that one may anticipate for giving away cows. Yet there are also potential dangers, for even an unintentional mistake in bovine charity could bring about a quite opposite result from what is expected. ${ }^{26}$ To illustrate how this is so, Bhishma narrates the story of a certain King Nriga. Nriga was a generous and conscientious giver of cows to brahmins. However, once he unwittingly gave a brahmin a cow that had wandered into his herd from that of another brahmin. The latter brahmin, the proper owner, noticing that his cow was missing, eventually found it with the other brahmin, who had received it as a gift from the king. After some altercation both brahmins approached the king. To rectify the mistake, Nriga begged the recipient brahmin to accept hundreds of other cows in exchange for this one; but the man declined, giving several reasons why this would not be possible. Nriga then offered a hundred thousand cows (!) to the brahmin whose cow had wandered away and which the king had then mistakenly given away in charity, but to no avail: the brahmin refused, saying that he accepts no gifts from the royal order. And so, explains Bhishma, as punishment, after his death the king had to live for countless years as a large lizard before being finally rescued and sent to heaven (for his many pious acts) by the highest divinity in his form as Krishna. ${ }^{27}$

This last story hints strongly at the Mahabharata's struggle to reconcile seeming contradictory principles within one vision of rightness and goodness that would be codified as dharma. And somehow, in the persistent pursuit of this vision as one of integrity among nature, humanity, and divinity, it appears that cows take an increasingly significant place. To be sure, their place is not regarded as that of subjective agency as we might understand it; rather, cows are in large part passive objects of possession,

\footnotetext{
${ }^{26}$ Another noteworthy unintentional mistake involving a cow in the Mahabharata relates to the epic's main story. Karna, the great warrior and arch-rival of Arjuna, while practicing archery in the forest, accidentally kills a brahmin's cow-one that had been supplying milk for the brahmin's sacrificial rites. The brahmin curses Karna that, while fighting in the impending war, his chariot wheel will become stuck in the mud, at which time his enemy will remove his head. Incidentally, we may note the connection between cow and earth in this curse (Bowles 2008, pp. xxxiii-xxxiv). 27The Bhagavata Purana 10.64 has an almost identical version of this story, adding that when the king dies, he is given a choice by Yama to either first enjoy results of his pious acts or to first suffer the results of his impious acts. Nriga chooses the latter, and thus he suffers life in the body of a large lizard, until Krishna saves him. Thereafter, Krishna delivers a speech warning of the great dangers of taking the property of brahmins.
} 
symbols and generators of wealth and well-being. And yet as embodiments of power-particularly as embodiments of maternal nurturing and, in the case of bullocks, embodiments of steadfast righteousness-cows become something substantially more than "just animals" in the Hindu imaginaire. As we continue this survey of literary cows, this trend extends further, with a considerable shift in the religious currents to a dominance of what may be called the "bhakti paradigm" or bhakti spirit, the spirit of devotion to a supreme deity for whom cows are integral to his identity and his ways of engagement in the world.

\section{The Bhagavata Purana-Cows in the World of Bhakti}

One of the most popular among classical Sanskrit texts in India remains to the present day the Bhagavata Purana. Doubtless the reason for its popularity is its extensive account of Krishna's life, especially of his early life as a charming and mischievous cowherd in the pastoral land of Vraja. While Krishna's winsome ways with his friends, relatives, and cows are captive to the imagination, there is also a persistent and coherently developed message throughout the text - that bhakti, devotion, is the most felicitous way to human perfection and the sublime. To get a sense of this vision and to relate it to what we have encountered thus far with regard to "bovinity," we look at some details of two key passages from the text's early portions before turning to relevant episodes in Krishna's life in a later portion of the text. Both early stories are allegorical in structure and both involve kings whose concern is the well-being of the earth, personified as a cow.

The first episode serves an etiological function, explaining the origin of the current cosmic age, kali-yuga - the fourth and last in a cycle of increasing discord and decreasing human capacities, especially for spiritual culture. ${ }^{28}$ In a prelude to the main story, a dialogue takes place

\footnotetext{
28 Previously, while introducing the Mahabharata, I noted its concern with the sense of "time's degrading influence." That text locates its events at the end of the previous cosmic age, dvaparayuga. The understanding is that the full force of degradation unfolds in the present age, the kali-yuga. The Puranic calculation of the Kali age's inception places it at ca. 3000 BCE, see Holdrege (2015, p. 319 , n. 2, and Ch. 1).
} 
between Dharma, in the form of a bull, and Earth, in the form of a cow (BhP 1.16.18-35). Dharma has lost three of his legs (indicating humanity's morally disabled condition) and, seeing that Earth is grieving, he asks her to identify the cause of her grief, suggesting several possible reasonsexploitation by unprincipled persons; neglect of prescribed sacrificial rites; drought and famine; unprotected women and children; neglect of the goddess of learning by lapsed brahmins; disturbed and unqualified kshatriyas; or the unregulated habits of the human population. Earth replies to Dharma initially by listing some forty virtues and qualities that, having their basis in the supreme Lord (bhagavan), have largely disappeared from the world due to the departure from the earth of Krishna (identified throughout the text as bhagavan). ${ }^{29}$

To explain briefly: This prelude dialogue is within the first of twelve "books" of the Bhagavata Purana, and the entire first book serves as a prelude to the remainder, the high point of which is Book 10, which tells specifically of Krishna's descent (avatara) to the earth. However, in this introductory Book 1, readers are introduced to the story by, in effect, telling its conclusion. Thus, after Krishna has come to the world and then, some 125 years later, has departed, the world languishes in this degenerated state.

\footnotetext{
${ }^{29}$ The concept of divinity as bhagavan is of great importance in Vaishnava Hindu traditions. Particularly because Krishna, the divine cowherd, is identified as bhagavan, it is worth noting a detailed definition of the term, given by the sixteenth-century theologian of the Caitanya Vaishnava tradition, Jiva Gosvamī: "He who is the very form of existence, consciousness, and bliss; who possesses inconceivable, multifarious, and unlimited energies that are of his own nature; who is the ocean of unlimited, mutually contradictory qualities, such that in him both the attribute and the possessor of attributes, the lack of differences and varieties of differences, formlessness and form, pervasiveness and centrality [madhyamatva] —all are true; whose beautiful form is distinct from both gross and subtle entities, self-luminous, and consisting entirely of his own nature; who has unlimited such forms that are manifested by his chief form called Bhagavan; whose left side is beautified by Lakșmi - the manifestation of his personal energy, suitable to his own form; who resides in his own abode, along with his associates, who are furnished with a form that is a special manifestation of his own splendor; who astonishes the hosts of atmaramas (those who take pleasure in the self) by his wonderful qualities, pastimes, etc., which are characterized by the play of his personal energy; whose own generic brilliance is manifested in the form of the reality of Brahman; who is the sole shelter and life of his marginal energy, called the living entities [jivas]; whose mere reflected energy are the modes of nature [gunas], visible in the unlimited phenomenal world-he is Bhagavan" (Gupta 2007, p. 33, quoting Jiva's Bhagavat-sandarbha 100).
} 
To continue the story, the earth-cow (dharani- "she who sustains") bemoans the pervasive influence of the current Kali age and its deleterious effect on herself, on the divinities, sages, ancestors, ascetics, and pious upholders of social traditions. She fondly remembers the time of Krishna's presence, when she was relieved from the burden of military hordes (alluding to the annihilation of armies in the Mahabharata war), a time when Dharma was relieved of his distress as well. It was a time of such joy that Earth's "hair" (suggesting grass) would "stand on end," suggesting an abundance of grass available for cows (BhP 1.16.35).

We next read that King Parikshit (sole surviving grandson of Arjuna, the Pandava warrior-king hero prominent in the Mahabharata epic), having become alerted to Kali's increasing influence in his kingdom, sets out from his palace to rectify the situation by reestablishing his authority throughout the realm (BhP 1.17). Eventually he comes upon an uncultured man dressed as a king, cruelly beating a cow and bull, which are trembling, crying, and urinating in their helpless state. Parikshit accosts the man, noting the contradiction between his dress and his behavior and, enraged, thunders, "For harming innocent beings, you deserve to be killed!"

Then, addressing the bull and cow, the king reassures them that he, upholding his duty as king, will protect them. He urges the bull to name the perpetrator of its mutilations - the loss of three of its legs. The bull replies thoughtfully, saying that it is difficult to identify the culprit, for there are so many theories of causation: One's own self, destiny, or one's disposition could be the cause; or else the cause may be impossible to determine by any means. King Parikshit congratulates the bull, identifying him as the embodiment of dharma and affirming his reply as fitting to the correct understanding of dharma. ${ }^{30}$ Further, he identifies the four

\footnotetext{
${ }^{30}$ Parikssit's affirmation of the bull's reply includes a reference to divine arrangement (1.17.23): Behind all possible causes is the Lord, whose energies are agocara, literally "absent of (or beyond) [human] range." The word alludes to cows (go) and their movement (cara) or the range for their grazing.
} 
"legs" of dharma, three of which are now destroyed, as four principles sustaining human well-being, namely austerity (or "ardor"-tapas), ${ }^{31}$ cleanliness (shaucha), mercy (daya), and truthfulness (satya). The first three of these have been destroyed respectively by indulgence in intoxication, unrestrained sexual activity, and pride. But now, explains the king, quarrel personified - the personage of the current age, Kali-tries to destroy even truthfulness, the last leg of the dharma bull (BhP 1.17.8-25).

The episode concludes with the king preparing to slay Kali (who had been impersonating a king while torturing the cow and bull); but when Kali abandons his disguise and throws himself in submission before the king, Parikshit relents. Sparing his life, Parikshit initially banishes the troublemaker; but upon Kali's plea for some place to remain within his kingdom (since his kingdom extends throughout the world), the king allows him to remain in five types of places. Wherever there is gambling, drinking, prostitution, animal slaughter, and accumulated gold, Kali would henceforth reside and exercise his pernicious influence. Nonetheless, the narrator reports on a hopeful note, in the end the king restores the bull's three lost legs and restores the cow's (the earth's) health by his responsible rule (BhP 1.17.28-42).

As mentioned, this episode can be read as an etiological story for the origin of the current age (kali-yuga), seen as a time of widespread cultural and environmental degradation. Significantly, prior to this episode, the Bhagavata extolls recitation of the Bhagavata as the best antidote to this condition. ${ }^{32}$ Within such recitation would be reminders of this cosmic time frame in which the debilitations of Kali are understood to be in effect, and this effect is understood to play out both for human beings and for animals. In particular, although the story just recounted concerns allegorical bovines, the implication is that while, as a whole, the principles of dharma and welfare of the earth suffer, real bovines in particular are

\footnotetext{
${ }^{31}$ Calasso (2015, p. 99) notes that "austerity" as a translation of tapas is a product of a Christianizing tendency, whereas ardor (or fervor) highlights its original meaning indicating the production of heat, as in the Latin tepor, a cognate of tapas. As will be discussed in Chapter 5, in considering Hindu ethics as an expression of virtue ethics, these four principles may appropriately be considered as basic elements for the cultivation of virtue.

${ }^{32}$ To the present day, formal Bhagavata Purana recitation is practiced widely, especially in India but now increasingly elsewhere, wherever the Indian Hindu diaspora resides.
} 
victims of the present age (even as, in this account, hope is held out in the restoration to wholeness of the earth-cow and dharma-bull).

We move on to the Bhagavata Purana's Book 4 to consider a second episode involving a king and the earth personified as a cow-in this case an account recalled from an age of relatively greater well-being, long before the present age of Kali. The king is Prithu, considered to be a "portion" of the supreme divinity Vishnu, and his queen, Archi, is counted as a portion of Lakshmi, Vishnu's divine consort. Sage Maitreya narrates how, at the time of Prithu's coronation, there had been famine in the land due to Prithu's predecessor's ill-motivated and wrongheaded governance. Taking his subjects' plight to heart, in a move that seems initially quite the opposite of Parikshit's behavior, Prithu resolves to force the earth to yield its bounty: Taking bow and arrow, he aims it at the earth which, out of fear, assumes the form of a cow and begins to flee from the king's presence. He gives chase, following her into outer space and back to earth, where she pleads with him (BhP 4.17.18), "O knower of dharma, to whom unfortunate creatures are dear, who are established as the protector of living beings, deliver me!"

Here, unlike in the Parikshit-Kali confrontation of Book 1, the earthcow is represented as having a voice of resistance. She protests to the king: Why is he attacking her who is innocent, who is a woman, who is the earth upon which all beings depend? Prithu defends his behavior: The earth has not been yielding grains, despite proper execution of sacrificial rites; she does not yield seeds of herbs and grains; and despite eating sufficient grass, the earth-cow is not yielding milk; hence, she is not at all innocent. And then the king brashly threatens the earth-cow: "With my arrows I shall pacify the hungry, distressed people with your sliced flesh" (BhP 4.17.25). Indeed, he even accuses the earth-cow of being a "false cow" (maya-gam; BhP 4.17.27) that he is justified in killing as the cause of suffering to living beings, which he will henceforth maintain without the earth's help, by the strength of his own mystic power of yoga (concentrated discipline of physical and mental self-restraint).

At this point, the earth humbles herself before Prithu, addressing him as the supreme, fully independent divinity Vishnu, the Lord who is beyond reproach. Although she asks him again why he, for whom dharma is of primary importance, desires to kill her, she recognizes him as the source of 
creation and cause of all conditions in creation. Hence his behavior is at once contradictory and wondrous. Then the earth-cow explains why she has been withholding her bounty: Until now her yields of grain, herbs, and seeds have been enjoyed by contemptible people, persons who have no spiritual vision or understanding. In consequence, she has been neglected and victimized by thieves, and her gifts have been misused for selfish ends rather than being offered in sacrifice. However, because Prithu, an expansion of Vishnu, is now the king, she wishes to cooperate with him, and she will do so if he arranges to bring a "calf" suitable for "milking" the earth.

Then follows a list of beings who, each with an appropriate "calf" and "milk container," are able to "milk" the earth for the particular substance of her or his desire. First, Prithu demonstrates the milking process by transforming the cosmic progenitor Manu into a calf, enabling Prithu to milk into his cupped hands all grains and herbs from the earth. Similarly, the world's sages make the celestial priest Brihaspati into a calf and milk the Vedic hymns into the senses; Indra, king of the heavens, becomes a calf for the gods, who milk the ritual soma drink into a golden pot. Cosmic demons draw liquor and beer into an iron pot, their calf being the devoted demon-born hero, Prahlada. Thus, all the various sorts of beings of this world and beyond-predator and prey animals, yogis, trees, and even mountains — receive their desired "milk" prizes, each with the help of appropriate "calves" (BhP 4.18.12-26).

Consistent with earlier texts, this story continues the association of cows with abundance. In addition, in this and in the Parikshit-Kali encounter, the Bhagavata Purana makes an explicit identification of cows and earth. In both instances, violence or the threat of violence to the earth-cow is featured, and in both there is verbal communication between a human and the (allegorical) bovine. As with almost all the narratives we have thus far considered, kings or divinities are involved, as protectors of a threatened world-as-bovine. But in the case of Prithu's encounter with the earth-cow, there is the surprising initial threat by the king against her. Also, in this case, unlike in the Mahabharata, there is a sense that dharma-closely linked to brahmins and cows_-can be properly upheld when the supreme divinity Vishnu (albeit initially with the threat of violence) intervenes. 
The Bhagavata Purana certainly regards Vishnu as the supreme divinity, consistent with a long tradition that regards him as superior to all other gods of the Rigveda. Yet the Bhagavata aims to establish Krishna, the cowherd boy of Vraja, as the original form of bhagavan, of whom Vishnu, in countless forms, is a primary manifestation. This distinction is made briefly early in the text, but the entire Book 10 (approximately one third of the entire text) celebrates Krishna as the actual supreme, primordial divine being. Without digressing into the theological details by which this argument is made, for us to note is the notion sustained in the text that, being — or despite being — the supreme God himself, Krishna enjoys the pleasure of acting and being regarded as an ordinary cowherd boy. Thus, the sequence of his adventures from birth to childhood and to youth urges readers/listeners to imagine themselves participating in these events, experiencing Krishna much as Krishna's friends and family in Vraja experience him. He is an ordinary cowherd boy, but then again, he is supraordinary in so many ways, including his stunning beauty and handsomeness, his charming, joking speech and mischievous smiles, and his irresistible dallying with Vraja's young cowherd maidens.

Here we can consider three Book 10 episodes relevant to our topic. To keep well in mind is the text's foregrounding of the bhakti principle, or what may be called the "bhakti paradigm." Bhakti is typically translated as "devotion" or "devotionalism," yet the rich import of the term for the tradition in which bhakti is foregrounded is best understood through such literature as the Bhagavata Purana. Important for us to be alert to in appreciating the spirit of bhakti is a sense of cultivated emotive, reciprocal relationality between human and nonhuman devotees and the divinityin this case Krishna. Such relationality operates within a "spatio-temporal 'neighborhood' of both mortal and non-human persons" (Frazier 2017, p. 177) that is inclusive of nonhuman animals and even of plants and trees. Further, it is in the Vraja neighborhood of bhakti that the sense of lila-divine play, pastime, or sport-comes to its full significance. ${ }^{33}$ Lila is contrasted with karma, action which invariably implicates the actor in

\footnotetext{
${ }^{33}$ Vraja (Hindi: Braj) is identified as an area in present-day northern India that straddles three statesHariyana, Uttar Pradesh, and Rajasthan. More importantly for the tradition, Vraja is Krishna's everexisting transcendent abode which Krishna manifests on the earthly plane when he exhibits his earthly childhood life. For a detailed explanation, see Holdrege (2013).
} 
the bound, embodied life of enjoyment and suffering, framed by birth, death, and rebirth, each time in a physical aggregation of previous actions, a mortal body. By contrast, divine lila carries no residue of karmic selfishness, and thus there is no impedance to the steady flow and swelling of selfless love, leading ultimately to a state of freedom said to be realized in a nonphysical, yet richly multifarious, counterpart to the land of Vraja on earth. In that nontemporal realm called Goloka-the realm (loka) of cows (go) - the same lila that Krishna and his associates enact in the temporal, physical realm is said to go on perpetually, with ever-expanding variation and selfless joy.

\section{Krishna and His Cows in Vraja}

Krishna is seven years old when his foster father, Nanda, chieftain of the Vraja cowherd district, begins preparations for the community's annual Indra worship ritual. When Nanda explains to his curious son the reasons why this ritual is performed, Krishna is unconvinced. "Why we don't worship Mount Govardhana instead, since this lush green mountain supplies everything needed for our cows, the direct source of our well-being?" Because Krishna is so lovably charming to Nanda and the other village elders, they are happily inclined to follow his proposal this year and see how it goes.

When Indra, the great storm-god of the heavens, sees that the Vraja villagers are irreverently neglecting his worship, instead dedicating all ingredients and rituals to a nearby mountain, in furious retaliation he sends world-inundating storm clouds over the town. A terrible tempest ensues, enveloping Vraja in torrential rain, hailstones, and blasting winds. The villagers, as well as the cows and other domestic animals, trembling with cold, all rush to Krishna, begging him (who had convinced them to neglect Indra's worship) to save them from the deluge.

Bent on teaching Indra a lesson while fulfilling his vow to protect his devotees, Krishna miraculously places his left arm under Mount Govardhana and raises it into the air, effortlessly balancing it on his hand "just as a child holds aloft a mushroom" (BhP 10.25.19). With the mountain now serving as a vast umbrella, smiling Krishna invites his family and 
all villagers, with their cows, to come take shelter under the mountain. Doing so, all are comfortably accommodated and, the text reports, for seven days Krishna stands, left hand keeping the mountain above them, unmoving from this position while all gaze upon him, none disturbed by hunger or thirst. After seven days, Indra withdraws the storm clouds, the villagers step out from underneath the mountain, and Krishna carefully sets it down in its previous position. The villagers are beside themselves with gratitude and praises for Krishna, who then unaffectedly returns to his "routine" lila of tending the cows.

Indra, now remorseful, comes personally before Krishna, bows before him, and offers him praises as cosmic father, primordial teacher, supreme Lord, and master of time. Acknowledging that Krishna has rightly humbled him, Indra regards Krishna's way of dealing with him as divine mercy and therefore begs Krishna for pardon and refuge. Krishna then blesses Indra to resume his duties as lord of the heavens, warning him not to again succumb to pride.

At this point in the narrative, the celestial cow Surabhi, together with her progeny, approaches and speaks to Krishna (here referred to as goparüpi-he who has the form of a cowherd): "You are our supreme divinity; lord of the world, please become our Indra-lord of cows, brahmins, gods, and saints!" 34 Then she, with the help of the heavenly Indra and other divinities, performs a ritual royal consecration, concluding with Indra addressing Krishna as "Govinda" (Indra of Cows). The episode ends with a display of natural abundance and harmony: The cows, out of joyfulness, drench the earth with their milk, rivers flow with various liquids, the trees flow with sweet sap, vegetables thrive without cultivation, and mountains yield jewels on their surfaces. Even predator animals are said to shed their vicious natures (BhP 10.27.18-27). ${ }^{35}$

\footnotetext{
${ }^{34}$ There are several stories about the celestial Surabhi cow in various Sanskrit texts, including the Mahabharata and as early as the Taittiriya Brahmana, a portion of the very early text, the Yajurveda. The BhP (8.8) mentions Surabhi (referred to as Havirdhani-she who provides ingredients for sacrificial rites) as the first of the beings that emerge from the Churning of the Cosmic Ocean by the gods and anti-gods, a story widely known throughout South and Southeast Asia.

${ }^{35}$ One can easily recognize in the BhP Govardhana episode the message of Vedic orthodox brahmanical yajna replacement with the bhakti paradigm, whereby the bhakti spirit and practices are contrasted with the ritualism of Vedic practices. Also, Indra's humiliation in this account contrasts
} 
In our second Book 10 narrative, a noteworthy similar testing of Krishna's divinity in which cows are involved is ventured by the cosmic demiurge, Brahma. There are sufficient features of this episode differing from the encounter with Indra to merit our attention, particularly its echoing of the Rigvedic story of bovine theft by the Panis.

In days prior to the encounter with Indra, when Krishna is just old enough to herd the calves, he roams the Vraja forest with the calves and with his young cowherd friends. Eventually the friends sit together to enjoy the lunch they have brought with them from their homes. While eating, after some time the boys notice that the calves have wandered off, and Krishna sets off alone to fetch them while the boys continue with their picnic. During Krishna's absence from both the boys and the calves, Brahma invisibly takes them all_all the boys and all the calves-and hides them away. Krishna, now alone, understands that this is the work of Brahma to test him, for Brahma had been observing Krishna's previous wonderful deeds, and he hoped to ascertain the limits to Krishna's power.

Krishna's simple solution to the problem of missing friends and their calves is to instantly replicate them all. By his unlimited divine powers, Krishna creates a perfect copy of each boy and each calf, each one exactly like its prototype, in both appearance and character. That afternoon, in these many forms, Krishna returns to each appropriate home and cowshed, where both human and bovine mothers joyfully welcome their would-be offspring. Because it is actually Krishna, the supremely attractive bhagavan, whom the mothers meet, their feelings of love for whom they think are their offspring redoubles. And with all their devotionally imbued attentions upon these boys and calves, these respective "mothers" unknowingly render devotional services to Krishna in a particular emotional mode of bhakti called vatsalya - the caring and protecting mood of parents and elders for children and dependents. The charade continues for an entire year, with the affection of the cowherd men and women for their sons intensifying from day to day, and that of the cows for their calves similarly increasing.

with his exalted identity in the Rigveda to highlight the more exalted position of Krishna as "Indra of the cows." 
Meanwhile, after only a moment by his own experience of time, Brahma returns to see how Krishna has reacted to his trick. To his surprise and astonishment, he finds Krishna playing with his friends and surrounded by calves just as before. Looking back to the boys and calves he has kept hidden, he is now confused: Which of them are the real ones? In this state of bewilderment, Krishna gives him a divine vision, in which all of Krishna's expanded calves and boys assume forms of Vishnu, with Vishnu's four arms and other insignia. Finally, Krishna reveals to the ever more astonished Brahma a vision of Vraja in which hunger, thirst, and anger are dissolved, and where naturally inimical animals and humans reside like friends.

We may recall that in the Rigveda is a story of cattle theft by the Panis, who hide the cows in a cave (or in/behind a rock). In this account of Brahma's cattle and cowherd theft, the specific location of their captivity is not indicated; only it is mentioned that they are kept "sleeping in the bed of maya," that is, they are kept under a sleep-like spell for one year's duration. In any case, the more important contrast to note here is between the Rigvedic sacrificial world and the Bhagavata's devotional world. The Rigvedic world is one in which the danger of scarcity is always to be overcome by keeping the sacrificial process - in which cows play an integral role-intact at all cost. The devotional world of Vraja in the Bhagavata Purana echoes to some extent the Rigvedic sacrificial world, but in contrast, this is a world of assured abundance, where threats of deprivation are always overcome by the object of devotion, Krishna. And this is assured because, after all, Krishna is an "ordinary" cowherd boy and he is the Indra of cows, Govinda, making him superior even to Indra, the lord of the heavens (BhP 10.13).

Our final episode from the Bhagavata's Book 10 takes us still further back in the life of Krishna, to his time as a toddler as he is doted upon by his foster mother, Yashoda. Here again, the theme is the power of devotion, again highlighting the vatsalya mood of parental affection, but now child Krishna displays his mischievous nature while showing how the products of cows — milk and its derivatives — become uniquely apt media for exchange in the "economy of love" (Hawley 1983, p. 283). And here again, the naughty thievery of Krishna is an echo of ancient dangers related 
to cows, now replayed on the register of divine pranks and the passion for fresh butter.

It is early morning, and Yashoda, wife of Nanda (the Vraja cowherd chieftain), is in the home courtyard churning yogurt. Yashoda's beloved child Krishna interrupts her work to suckle her breast milk; but then their exchange is interrupted when Yashoda must dash to the kitchen to save some cooking milk from boiling over. While Yashoda is thus preoccupied, Krishna, now upset by this interruption, shows his spite by smashing the pot in which yogurt was being churned, and makes off to a side room with part of the pot to enjoy its contents. When his mother finds him, little Krishna is sharing the contents with some monkeys. Seeing Yashoda approaching him with a stick in hand, Krishna flees "as if afraid," but she soon apprehends him. Seeing the child's fear and his tears, Yashoda discards the stick. But then she resolves to bind Krishna with a rope to something immovable, to teach him a lesson and to prevent further mischief.

The Bhagavata's main narrator, Shuka, points out that Krishna, as bhagavan, has neither beginning nor end, neither interior nor exterior. Hence, it is impossible for anyone to capture and bind him. Nonetheless, Yashoda is resolved to do so. Since the first rope she wraps around Krishna's small belly is slightly too short, she ties a second rope to the first. Yet, strangely, the combined ropes are still too short, as are three ropes and any number more that she adds to the previous ones. When Krishna sees that Yashoda now perspires with her determined effort, he finally accedes to her wish and allows himself to be bound by her, to a large wooden grinding mortar. $^{36}$ The narrative concludes with an explicit lesson to be learned: The supreme Lord, the butter thief Krishna, cannot be attained by anyone who would try by one's own power; yet he allows himself to come under the control of his devotees.

\footnotetext{
${ }^{36}$ As the story continues in the $\mathrm{BhP}$ (10.9), when Yashoda is not looking, Krishna will drag the mortar to which he is tied out into the courtyard, causing it to become wedged between two trees. Continuing to pull the mortar, he forces these trees to come crashing down, thereby freeing two celestial beings who had been cursed to stand as trees for earlier improprieties. The motif of curse or sinful act, then punishment by lower life form, followed by release by a divinity, is widespread in the Sanskrit epics and Puranas and beyond. Here we may be reminded of the Nriga story of the MBh and BhP. In both cases Krishna's saving grace is the main message, but also, we are reminded of the Indic notion of embodiment - that all living beings, as non-temporal spirit (atman), reside temporarily in physical bodies, each body appropriate to previous action (karma). This will be further discussed in Chapter 5 in relation to our consideration of Hindu animal ethics in general.
} 
I have saved this final Bhagavata Purana reference to cows (or, more specifically, to dealings with cows' products) for last, as a lead-into the last part of our discussion on the Hindu literary bovine imaginaire. We continue to focus on the bhakti tradition, especially of Krishna-bhakti (often referred to as Vaishnavism-faith in Vishnu as ultimate), moving into its late medieval and early modern manifestations in vernacular languages, particularly Hindi and its Vraja dialect, Vraja-bhasha. ${ }^{37}$ Yet for some authors, Sanskrit remains the preferred language. This later Vaishnava tradition invariably draws inspiration from the Bhagavata Purana, often explicitly, and less frequently or explicitly it may also draw from earlier literature. However, at times the later Krishna-bhaktas (devotees of Krishna) may explicitly distance themselves from Vedic literature such as the Rigveda to highlight the contrast between their own devotional world-transcendence and the perceived mundanity of the latter.

\section{Vraja Bhakti Poetry-The Buttery Sweet Language of Love}

We move forward to the sixteenth century to consider a poem attributed to Surdas, an important figure in the late medieval north Indian landscape of Krishna-bhakti. The poet invites his readers/listeners to picture in detail the scene of child Krishna's butter thieving. Gopal (an endearing, popular name of Krishna, meaning "cowherd") is described as being "in the butter," the shimmering color of which contrasts with his own "dusk-toned body." Then ensues a cascade of images mirroring and echoing a sense of divine grace occurring in liquid form, the freshly churned butter "trickling down his face to his chest / As if the far ambrosial moon rained beams on loves below." Then, shifting the metaphor, Surdas suggests a sense of excitement and danger: Gopal has "risen to peer from his lair," perhaps like a lion cub, to look about and confirm that no one is looking, "and then / he cheerfully feeds his friends." Surdas' audience knows (from the Bhagavata Purana

\footnotetext{
${ }^{37}$ In a quite different register of vernacular literature, the Rajasthani oral folk epic of Pabūjī, Pābūjī ro pavāro, celebrates Pabūijìs heroism often involving the protection of cattle from cattle raiders. $\mathrm{He}$ is regarded as a form of the divinity Rama and is worshiped by Rebarī camel herdsmen, see Turek (2006, pp. 300-305).
} 
account) that these "friends" are monkeys, whose impish company points to Krishna's inclination to freely extend his kindness to all beings. The poem's colophon turns our attention to the intense affection of Krishna's beloveds (the "loves below"), the gopi maidens, who have delightedly witnessed Krishna's mischief:

... Seeing Sur's Lord in his boyish fun, the maidens start, love-struck and weakened,

Until their hearts are lost to speech in thought after thought after thought.

(Hawley and Juergensmeyer 1988, pp. 105-106)

Milk and its derivatives have been prized and praised in Indian literature from the time of the Rigveda. Late medieval vernacular bhakti literature expands this tradition considerably, taking as the seed for further reflection especially the Bhagavata Purana's account of Krishna's yogurt and butter "theft" that we have just seen. Such further reflections may be taken as further "churning" of the milk-as-bhakti motif, whereby the notion of churning to extract something especially desirable, as a creative act, also suggests resonance with a celebrated Puranic churning storythe Churning of the Cosmic Ocean. ${ }^{38}$ Yet Krishna's butter theft may also be regarded as an undoing of cosmic churning, wherein "the sea of milk products that the butter thief unleashes is the sea of love" (Hawley 1983, p. 305). Whereas the Puranic story is an affirmation of dharma's cosmic order (in which there is a foiled attempt by a demon to steal the ambrosia of immortality from the gods), Krishna's successful butter theft is a playful shattering of dharma's seemingly rigid boundaries, allowing to prevail what the bhakti traditions hold to be essential for dharma to be properly realized, namely divine love.

\footnotetext{
${ }^{38}$ This story has numerous tellings, especially in various Puranas. It is also found in Southeast Asian cultures, famously illustrated for example at Ankor Wat in Cambodia. In the Bhagavata Purana, Book 8, the account features the involvement of several forms of Vishnu, one of which is Mohini, a female form that he manifests to foil the demons' attempt to take for themselves the ambrosia of "immortality" which they, in cooperation with the gods, had churned from the Cosmic Ocean. See Gupta and Valpey (2013, pp. 3-11) for a summary of this episode as representative of broad themes in the BhP.
} 
The poem just quoted, so rich in imagery of savorable fluidity, invites us to partake in a vision of a light-hearted and mildly forbidden sort of divine love. Gopal-Krishna-in his thieving stealth cannot hide his beauty, compared to the moon, which in much Indic literature is associated with ambrosia. That Krishna's moonlike face "rained beams on loves below," implies that Krishna's young cowherdess beloveds (as well as the older mothers, from whose houses Krishna steals butter) are the receivers of his "drop after drop" curd-like flowing love. These maidens are "love-struck" by witnessing Krishna's artless beauty as he freely shares the butter with his monkey friends. The flow of yogurt and butter, as a downpour of mercy, echoes the Rigvedic hope for Indra to bestow blessing in the form of rain. And this flow precipitates a cascading flow of thought ("thought after thought after thought") that arrests speech, possibly alluding to the Rigveda's preoccupation with right and poetic speech by which the divinities may be pleased and bestow their bounty. Here, in the overwhelming power of Krishna's beauty and love, speechless thought prevails, since speech, with all its clumsy limitations and proneness to misunderstanding, fails to do justice to the longing heart.

Ironically, of course, this song of Surdas is constituted of speech. Yet it also alludes to the other essential function of the mouth, namely tasting and eating. The traditions of Krishna-bhakti have a highly developed culture of vegetarian cuisine; and complementary to devotees' alimentary concerns of preparing the most tasty and tasteful food offerings for Krishna is a sophisticated theology of aesthetic taste. ${ }^{39}$ Integral to the vocabulary of devotional aesthetic taste, milk and milk products are often referred to as implicit vehicles for the communication of bhakti in the mode of sweetness (madhurya-bhava), both because of the literal sweetness of dairy and because they are associated with Krishna's pastoral way of life, in contrast to the mode of lordship (aishvarya-bhava) that predominates in the worship of Vishnu. ${ }^{40}$

\footnotetext{
${ }^{39}$ Present-day Vaishnavism, like most other Hindu brahmanical traditions, calls for a strict vegetarian diet. A vegan diet is now becoming increasingly accepted in recognition of current dairy farming malpractices, but Hindu classical traditions do not consider this option, apparently on the assumption that all dairy products will be obtained from well cared for, protected cows. For further discussion of this issue, see Chapters 4 and 5.

${ }^{40}$ A sixteenth-century narrative "commentary" to the Bhagavata Purana, Sanatana Goswami's BrihadBhagavatamrita (2.6.120-124; Dāsa 2005), celebrates Krishna’s festive eating habits with a detailed
} 
We could find any number of later literary works that highlight the aspect of "sweetness" that dominates Krishna-bhakti, but in relation to Krishna's identity as cowherd one or two excerpts may suffice. A Sanskrit work intended as a meditational aid for Krishna-bhakti practitioners is Raghunathadasa's Vraja-vilasa Stava, "praise song on the pastimes of Vraja" (sixteenth century), which offers an otherworldly vision of Krishna's cows:

The hooves of Śrī Krishna's Surabhī cows are decorate with sapphires, their horns are gold-plated, and their white cheeks have broken the snow-capped mountain peaks' pride. I pray these Surabhī cows may protect us. In the company of Balarāma [Krishna's brother] and His other friends, and his own body splendidly covered with the dust raised by their hooves, the prince of Vraja [Krishna] daily enjoys a great festival of protecting and milking the cows. With great happiness he eagerly enjoys pastimes with them in the great forests and on the grand hills and river banks of Vraja. Let me worship these Surabhī cows. Glory to Padmagandha, the favorite bull of the enemy of Baka [Krishna], whose handsome horns are covered with gold and studded with jewels, whose hooves are splendidly decorated with sapphires, and whose fine neck bears a swinging garland of reddish flowers. Sometimes Lord Krishna feeds the calves, attentively placing small bunches of soft fresh grass in their mouths, and sometimes he very carefully massages their legs. I yearn to one day see these calves of Lord Krishna jumping and frolicking in Vrindavan. (Raghunāthadāsa 1922, pp. 108-111, vv. 44-47)

Such eulogistic meditations as this would be used by practitioners of bhakti-yoga-especially by renunciant practitioners-to pursue and enhance their development of constant absorption in remembering Krishna, including his names, forms, attributes, pastimes, and associates, including his cows.

A close associate of Raghunathadasa, Jiva Gosvamin, also includes a meditation on Krishna's interactions with his cows in his lengthy Sanskrit elaboration of the Bhagavata Purana's tenth book, Gopala-champu. There he describes how Krishna's foster father Nanda has just decided to permit Krishna to start herding the cows, graduating from herding the calves now

description of his rich diet in his atemporal realm, Goloka. His midday meal begins with sweet preparations that include several dairy items, and other dairy items (go-rasa) also come later in the meal. 
that the boy has turned six years old. The first day performing his new duty is rich with delightful formalities:

The arrangements for going to the forest were as follows. Putting the priests in front with songs, music, and auspicious verses, bringing the cows near and worshiping them by offering foot-wash and arghya [a ritual honorific liquid mixture], feeding them sweet chick peas, respecting them with obeisances and circumambulation, and then offering the same respects to the priests, Kṛ̣na [Krishna], with his elder brother, remained standing in front of Nanda who had his hands folded. Nanda offered him a jewelled stick and Yaśoda put tilaka [ornamental auspicious clay marking] on his forehead. (Swāmi, n.d., p. 207; Gopāla-campū 1.12.34) ${ }^{41}$

Significantly, in this passage the cows take the role of venerable deities and Krishna, despite-or because of - being the supreme bhagavan, offers them honor with all the standard ritual forms. ${ }^{42}$ That cows come to be regarded as distinctly venerable we have seen from Bhishma's instructions in the Mahabharata, and this notion prompts us to look briefly at a contemporary Sanskrit ritual manual of ritual details for the honoring of cows.

\section{Compilations-Trails Toward Modern Cow Care}

The book Gavārcanaprayogah ("Procedure for the Worship of Cows") is a compendium of instructions on all formal aspects of cow veneration. It is patterned after other Hindu worship ( $p$ uja) manuals that guide votaries in their service to the various divinities housed in temples throughout India. ${ }^{43}$

\footnotetext{
${ }^{41}$ In Vanamālidās' (2002) edition of Gopāla-campū with Sanskrit and Hindi translation, the same passage is 1.12 .26 .

42 See Patton (2009), passim, for a germane discussion on the widespread pattern of gods performing religious rites of worship.

${ }^{43}$ Such manuals are typically produced by follows of Hindu Smarta traditions, those whose practices are based on several Puranas, and which enjoin the worship of five deities-Ganesha, Surya, Durga, Shiva, and Vishnu. Also, that the author of this manual is a Smarta is suggested by his title 'Pandita'. This particular manual also includes some elements from Tantric traditions. Both these traditions are
} 
First, there are preparatory procedures such as collecting items for worship, meditation on Vishnu's form, and a short pranayama (breathing exercise). The next section provides several mantras-verbal formulas-applicable for remembering, praising, and petitioning cows, including appropriate mantras from the four Vedas, a mantra for protecting cows, and a mantra titled "means for increasing cow milk." This section is followed by procedures for performing ritual fire oblations (homa) dedicated to cows. Then come instructions for observing occasional vows (vrata) in relation to cows at specific times of the year, followed by detailed instructions on the correct way to give cows (and bulls) in charity, for different purposes (e.g., to counteract sinful acts; to become free from debt; or for attaining liberation). Next is a collection of prayers and hymns, including a surabhi-kavacham - a protective mantra that calls upon the various physical features of the cow to protect oneself in all sorts of circumstances. The book concludes with a bovine miscellany that includes instructions such as how to prepare panchamrita, "fivefold nectar" consisting of cow's milk, yogurt, clarified butter, cow dung, and cow urine-a mixture commonly used in the worship of temple images, especially of Krishna.

As a Sanskrit ritual manual (with brief Hindi commentary), the Gavārcanaprayogah can be seen as a textual record of an effort to establish the full ritualization of cow worship, on par with other Hindu worship practices and objects of worship. The use of Sanskrit further underscores a sense of timeless legitimacy, locating cow veneration as a pan-Indian practice and linking it to the brahmanical, or priestly, milieu.

Our final text to consider in this chapter expands the spirit of the Gavārcanaprayogah to promote cow care. This consists of two large hardbound volumes in Hindi, special issues of Gita Press' semi-periodical Kalyana. One volume is titled Go Arkkh (Cow Issue) and the second is Goseva Ankh (Cow Care Issue). Both are collections of varied texts, mainly short articles by pundits, traditional teachers, gurus, and Indian scholars. ${ }^{44}$

(largely) distinct from that of the Vaishnavas mentioned earlier, for whom the sole object of worship is Vishnu or Krishna. "Sole" object means that nonetheless, on certain occasions, particular divinities or indeed cows might be given veneration by Vaishnavas, albeit as associates of Vishnu/Krishna.

${ }^{44}$ Here are a few samples of subjects treated in these writings, from the Go Ankh volume (translated article titles): "Prayers to Kāmadhenu by Brahmā, Vishnu, and Shiva"; "Consideration of the Dharma and Non-dharma of Ploughing"; "Mother Cow"; "The Importance of Cow Eulogy and 
The aim of these two compilations appears to be to provide Hindi readers with a compendium of Sanskritic cow lore and of later reflection on this lore. Amidst the striking extent and variety of these writings, of particular note for us presently is the occasional article linking cow care with the practice of nonviolence (ahimsa) and with Indian nationalism. How these concerns become linked will be the subject of the next chapter. ${ }^{45}$

In relation to our central concern, namely to discern basic elements for a modern Hindu animal ethics, one might wish to see the focus of this chapter extended beyond the bovine imaginaire. Clearly, the narrow focus maintained here is intentional, but as we proceed, it shall become more apparent both why bovinity is the center of attention and how careful reflection on cow and cow care may serve as a lens through which a comprehensive Hindu animal ethics may be articulated.

\section{Concluding Reflections}

In this necessarily brief survey of Hindu textual material related to cows, much has been excluded. Yet from what we have considered, definite themes and motifs emerge. As a preliminary effort to bring these features

Cow Protection"; "Cow Killing Is the Same as Human Killing"; "The Glories of Cows in Āryan Literature"; "Worshipable Mother Cow Is Directly Nārāyana (Vishnu)"; "The Story of the Primordial Cow-Mother, Surabhi”; "Cow-Wealth Versus Tractor"; "Cows-The Foundation of the Rajasthan Maru District's Economy”; "Cow Dung, Lakshmi’s Residence”; "Cow Care and Cow-Related Vows in the Svāminārāyana Tradition"; "Devotion to Cows in the Sikh Tradition"; "The Position of Cows in Buddhist Literature"; "Testing Milk Cows"; "Cows of Western Countries”; "Advice for Breeding and Protecting Cows"; "Ancient Cow Shelters and Scriptural Rules for Cow Protection"; "Let Cow Killing Be Stopped”; “The Benares Śrī Kāŝî Jīvadayā Vistārin̄i Cow Shelter and Animal Shelter"; "A Short History of the Cow Protection Movement"; "The Modern Slaughterhouse 'Al Kabir"; "Statements of Great Men and Cow Devotees on Stoppage of Cow Killing"; "Greatness of Foreign Cows-Some Memories"; "Cows and Islam"; "Cows and Bulls on Indian Currency"; "Attaining the Lord by Serving Cows.”

${ }^{45}$ See Mukul (2017, pp. 289-316) for a summary history of the Cow Protection movement, especially after India's independence (1947) and how Gita Press, especially through its periodical Kalyan, took an active role therein. Mukul notes that the special issue Go Ankh (663 pages), first published in 1945 , and fifty years later the similarly voluminous Goseva Ankh, represented the Gita Press' engagement with the cow on three levels: ritualistic, devotional, and economic (pp. 291-296; 422-424). This engagement had started long before 1945 and has continued to the present, especially in the regular issues of Kalyan, connecting the importance of the cow to Hindu life and expressly promoting legislation against cow slaughter. 
of a Hindu bovine imaginaire together, it may be helpful to conceptualize them in terms of two sorts of polarity. One polarity stretches between the two emic (indigenous) terms dharma and bhakti. These express, on the one hand, the tradition's concern with ethics as an emphasis on maintenance of cosmic order (dharma) and, on the other hand, the tradition's concern to foster devotion (bhakti) toward an ideal being (in our examples, centrally Krishna, who is fondly remembered as a cowherd boy). Put another way, while dharma is concerned with establishment and maintenance of boundaries, bhakti concerns the impulse to extend and go beyond boundaries. How these two valences relate to each other is a central concern of the Bhagavata Purana. This polarity we might designate the "values polarity."

This range of values is served by a second, what we might call "meaning polarity," spanning between literal and figurative meanings of language. The Rigveda's rich referencing of "cow" and "bull" provides a full range of literal to figurative meanings for these terms, unfolding images and ideas that collectively create patterns of human concern that link humanity with nonhuman animals, nature as a whole, and an invisible world of divine beings and powers. Through these meanings, cows-actual cows-are positioned as embodiments of both dharma and bhakti. At the same time, in this range of meanings, cows are symbols, in that they mark boundaries between the finite and the infinite (Neville 1996, p. 69).

By now it may be clear that thus far I have carefully avoided a controversial topic, namely the practice (or alleged practice) of ritual cow sacrifice in the early tradition. Also lacking here is any discussion about the development of ahimsa ideology, which is closely related to early and current cow slaughter controversy. As with the subject of cow care and Indian nationalism, so these will be subjects of our next chapter.

\section{References}

Bhāgavata Purāṇa. 1965. Śrīmad Bhāgavata Mahāpurānam, ed. Kṛ̣naśanikara Śāstrī. Ahmedabad: Śrībhāgavatavidyāpīṭh.

Bhāgavata Purāna. 1976. Śrìmad Bhāgavatam, trans. A.C. Bhaktivedanta Swami Prabhupāda. Los Angeles: Bhaktivedanta Book Trust. 
Biardeau, Madeleine. 1989. Hinduism: The Anthropology of a Civilization. New Delhi: Oxford University Press.

Biardeau, Madeleine. 1997. Some Remarks on the Links Between the Epics, the Purānas, and Their Vedic Sources. In Studies in Hinduism: Vedism and Hinduism, ed. Gerhard Oberhammer. Vienna: Der Östereichischen Akademie der Wissenschaft.

Bowles, Adam (trans.). 2008. Mahābhārata Book Eight_Karna Volume Two. New York: New York University Press and JJC Foundation.

Brockington, John. 2003. The Sanskrit Epics. In The Blackwell Companion to Hinduism, ed. Gavin Flood, 116-128. Oxford: Blackwell.

Calasso, Roberto. 2015. Ardor. London: Random House.

Das, Bharat Chandra (Harsha B. Wari). 2013. Timeless Stories of Gomata from Puranas and Other Classics_-In Support of Go-Raksha. Guwahati, Assam: Center for Traditional Education.

Dāsa, Gopīparāṇadhana (trans.). 2005. Bṛhad Bhāgavatāmrta of Śrīla Sanātana Gosvāmī. Los Angeles: Bhaktivedanta Book Trust.

de Nicolás, Antonio T. 1976. Four-Dimensional Man: Meditations Through the Rg Veda. Stony Brook: Nicolas Hays.

Feller, Danielle. 2004. The Sanskrit Epics' Representation of Vedic Myths. Delhi: Motilal Banarsidass.

Frazier, Jessica. 2017. Hindu Worldviews: Theories of Self, Ritual and Reality. London: Bloomsbury.

Ganguli, Kisari Mohan (trans.). 1991 [1970]. The Mahabharata of KrishnaDwaipayana Vyasa. New Delhi: Motilal Banarsidass.

Glucklich, Ariel. 2008. The Strides of Vishnu: Hindu Culture in Historical Perspective. New York and Oxford: Oxford University Press.

Go Añkh_Kalyāna No. 1773. Samvat 2072/2015 [1947]. Gorakhpur, Uttar Pradesh: Gìtā Press.

Goldman, Robert P. 2005. Rāmāyaṇa-Book One-Boyhood, by Vālmīki. New York: New York University Press.

Gonda, J. 1985. Pūsan and Sarasvatī. Amsterdam: North-Holland.

Gosevā Ar̀kh_Kalyāna No. 653. Samvat 2072/2015. Gorakhpur, Uttar Pradesh: Gìtā Press.

Grimes, John. 1996. A Concise Dictionary of Indian Philosophy: Sanskrit Terms Defined in English. Albany: State University of New York.

Gupta, Ravi M. 2007. The Caitanya Vaiṣnava Vedānta of Jìva Gosvāmī: When Knowledge Meets Devotion. London: Routledge.

Gupta, Ravi M., and Kenneth R. Valpey (eds.). 2013. The Bhägavata Purāna: Sacred Text and Living Tradition. New York: Columbia University Press. 
Hawley, John Stratton. 1983. Krishna, the Butter Thief. Princeton: Princeton University Press.

Hawley, John Stratton, and Mark Juergensmeyer (trans.). 1988. Songs of the Saints of India. Oxford: Oxford University Press.

Hiltebeitel, Alf. 2011. Dharma: Its Early History in Law, Religion, and Narrative. Oxford: Oxford University Press.

Holdrege, Barbara A. 2013. Sacred Geography_Vraja-Dhāman: Krishna Embodied in Geographic Place and Transcendent Space. In The Bhāgavata Purāna: Sacred Text and Living Tradition, ed. Ravi M. Gupta and Kenneth R. Valpey, 91-116. New York: Columbia University Press.

Holdrege, Barbara A. 2015. Bhakti and Embodiment: Fashioning Divine Bodies and Devotional Bodies in Krṣna Bhakti. London: Routledge.

Jamison, Stephanie W., and Joel P. Brereton (trans.). 2014. The Rigveda: The Earliest Religious Poetry of India. New York: Oxford University Press.

Kam, Garrett. 2000. Ramayana in the Arts of Asia. Singapore: Select Books.

Knipe, David M. 2015. Vedic Voices: Intimate Narratives of a Living Andhra Tradition. Oxford: Oxford University Press.

Macdonell, Arthur Anthony. 1917. A Vedic Reader for Students. Madras: Oxford University Press.

'Maithilạ̣’ Pạ̣dita Gañgādharapāṭhakah. Vikram S. 2068/2011. Gavārcanaprayogah-Sațīka-țippan̄i-vibhūsita-gosambandhi-vividhānuṣthānasamanvitạ. Pathmeḍa, Rajasthan: Śrī Kāmadhenu Prakāśana Samitih.

Maurer, Walter H. 1986. Pinnacles of India's Past: Selections from the Rgveda. Amsterdam: John Benjamins.

Mukul, Akshaya. 2017. Gita Press and the Making of Hindu India. Noida: HarperCollins.

Myers, Michael W. 1995. Let the Cow Wander: Modeling the Metaphors in Veda and Vedānta. Honolulu: University of Hawai'i Press.

Neville, Robert Cummings. 1996. The Truth of Broken Symbols. Albany, NY: State University of New York Press.

Olivelle, Patrick. 1998. The Early Upanisads: Annotated Text and Translation. New York and Oxford: Oxford University Press.

Patton, Kimberley Christine. 2009. Religion of the Gods: Ritual, Paradox, and Reflexivity. Oxford: Oxford University Press.

Prabhupada, A.C. Bhaktivedanta Swami Prabhupāda, and Hridayananda Das Goswami (trans.). 1993. Śrimad Bhägavatam, Cantos 1-12 in 18 vols. Sanskrit Text, Translation and Commentary. Los Angeles: Bhaktivedanta Book Trust. 
Raghunāthadāsa. 1922 [1329 Bengali Sāl]. Vraja-vilāsa Stava. In Stāvāvalī. Murśidābād: Śrī Rāmadeva Miśra.

Rāmsvarūpdās. 2013. Go Bhaktamāl (Pūrvādh), Gorañjanı̄ Kavittamayī Tì̄ā tathā Bhāvabodhinī Vyākhyā Sahita. Pathmedā, Rajasthan: Śrī Gopāl Govardhan Gośālā.

Ranganathan, Shyam (ed.). 2017. The Bloomsbury Research Handbook of Indian Ethics. London: Bloomsbury.

Sathaye, Adheesh. 2011. Magic Cows and Cannibal Kings: The Textual Performance of the Viśvāmitra Legends in the Mahäbhärata. In Battles, Bards, Brāhmins: Volume 2, Papers from the 13th World Sanskrit Conference, Edinburgh 2006, ed. John Brockington, 195-216. Delhi: Motilal Banarsidass.

Smith, Brian K. 1998 [1989]. Reflections on Resemblance, Ritual and Religion. Delhi: Motilal Banarsidass.

Srinivasan, Doris. 1979. Concept of Cow in the Rigveda. Delhi: Motilal Banarsidass.

Sukthankar, Vishnu S. (ed.). 1966. The Mahābhārata, Critical Edition, vol. 17. Anuśāsanaparvan, R. N. Dandekar. Poona: Bhandarkar Oriental Research Institute.

Swāmi, H.H. Bhānu. n.d. Gopāla-campū [of] Śrīla Jìva Gosvāmī. Chennai: Vaikuntha Enterprises.

Turek, Aleksandra. 2006. India in Warsaw. Indie $w$ Warszawie. Tom upamiętniajacy 50-lecie powojennej historii indologii na Uniwersytecie Warszawskim (2003/2004), ed. D. Stasik and A. Trynkowska, 300-305. Warsaw: Dom Wydawniczy Elipsa.

Vanamālidās Śāstrī. 2002. Śrī Gopāla-campū of Jìva Gosvāmin (Pūrva-campū). Vrindavan, Mathura, India: Gopinath Gaudiya Math.

Whitney, W.D. 2009. Atharva-Veda Samhitā, vol. 2. Delhi: Parimal Publications. Witzel, Michael. 2003. Vedas and Upanișads. In The Blackwell Companion to Hinduism, ed. Gavin Flood, 68-98. Oxford: Blackwell. 
Open Access This chapter is licensed under the terms of the Creative Commons Attribution 4.0 International License (http://creativecommons.org/licenses/by/ $4.0 /$ ), which permits use, sharing, adaptation, distribution and reproduction in any medium or format, as long as you give appropriate credit to the original author(s) and the source, provide a link to the Creative Commons license and indicate if changes were made.

The images or other third party material in this chapter are included in the chapter's Creative Commons license, unless indicated otherwise in a credit line to the material. If material is not included in the chapter's Creative Commons license and your intended use is not permitted by statutory regulation or exceeds the permitted use, you will need to obtain permission directly from the copyright holder.

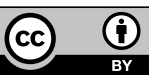

